\title{
Henry David Thoreau
}

\section{Boceto biográfico}

NACIO Henry David Thoreau el 12 de julio de 1817, en Nue1 va Inglaterra, cerca de Concord; murió el 6 de mayo de 1862 , también en Nueva Inglaterra. Lo enterraron en Concord, en uno de esos cementerios floridos, en donde se mezclan jubilosamente el verdor del césped, la blancura de las tumbas y el azul penetrante del cielo. Nació, vivió, sufrió y murió en su país puritano, clavado como un poste ante el prejuicio y la rutina. Ya era, desde viviente, estatua de sí mismo - y lo es. Dijo tantas verdades - y tan hondas- que hasta hoy sus palabras arden como brasas, quemando paladares, oidos y manos de los atrevidos que hasta él se allegan. $\mathrm{Si}$ alguien tuvo pluma de fuego, la suya es; pues que no asordó con clamores, sino que taladró con cauterios. Pudiendo burilar un estatuto, prefirió desbrozar maleza. Su palabra ebúrnea, como hecha a cincel, se trocó en piqueta y hacha de pioneer. Perteneció a la vieja estirpe de los Cotton Matter y los Jonathan Edwards, pero sus labios de perenne protestante reventaban de espuma, esa espuma de "leche de la tèrnura humana". Estirpe de profeta, clamaba como. Isaías, pero tenia el corazón contrito de Job. No hay en su obra otro "Cantar de los Cantares" que los de Walden y Week, porque sus perpetuos esponsales con el deber saben a ceniza; a Cantar hecho de Eclesiastés.

Era nieto de un marinero y aventurero de la isla de New Jersey. De él sin duda heredó la salvaje independencia y el brioso individualismo que signan su blasón. El abuelo abandonó el azar para hacerse mercader en 1770 . Seis años más tarde se proclamaba la independencia de las Middle Colonias. Pero el viejo Thoreau no te- 
nía necesidad de proclamación alguna, pues para él jamás hubo otra cosa que libertad y sólo libertad en su horizonte.

Habia sangre francesa en aquel indomeñable John Thoreau. aventurero, de donde provenían su racionalismo y su concisión. También ironía que, al cabo del tiempo, fuera flor del estilo de su combativo nieto. Los puritanos de verdadera cepa no usaban esos esguinces felinos de Desobediencia civil y $L a$ vida sin principio. E1 predicador que jamás estuvo ausente de Emerson se trocaba en un sagitario incansable, demonio familiar de $H$. D. Thoreau.

$\mathrm{El}$ bosque fué su preceptor. Claro que tragó lecturas, y de las mejores, y del mejor modo posible, esto es, digiriéndolas parsimoniosamente, asimilándoselas sin gula, con sabiduría. Primero, en la Concord Academy. Después, en Harvard: tremenda proeza ésta para una familia de tan escuetos recursos como la suya.

El bosque fué su preceptor y así él pudo ser preceptor de sus vecinos y conciudadanos. Su vida consistió en aprender y enseñar: con la palabra, con el escrito, con el ejemplo, con la ley, por la ley, contra la ley.

A los veintiứn años ya era lecturer de Liceo. Como a los veinticuatro lo dejaron sin su escuela, clausurada; no tuvo otra salida mejor que irse a vivir en casa de Emerson. Ahí trabó amistad con el insigne grupo de los "trascendentalistas" (i él lo era ya!). Gran catador de hombres, Emerson quiso que colaborase en su periódico Diet, y tal confianza puso en el joven maestro que cierta vez, durante una ausencia del autor de Hombres simbólicos, en abril de 1843, Thoreau dirigió el periódico.

En medio de esta juventud, madurada a fuerza de meditaciones, el amor al prójimo ocupó el puesto del amor a la mujer, forma de amarse a sí mismo. Se sabe de un nombre, sin embargo, el de Ellen Sewall, con quien Henry David soñó alguna vez. Pero Ellen prefería a John, el hermano de Henry - a John, que murió súbitamente en 1842.

Pronto concluiria también el tránsito de Henry David por el mundo. No lo amparó la muerte, es verdad, como a su hermano: los bosques de Walden le tendieron los brazos, cubriéndolo de soledad y fortaleza. En adelante vivió sólo para las esencias, reñido con lo consuetudinario. Simbólicamente escogió para iniciar su ya ininterrumpida cuaresma el día 4 de julio de 1845 , en que se cumplían 69 años de la Independencia Nacional. 
El bosque fué su preceptor - y su libertador. Porque ese mismo verano de 1845, Thoreau dió comienzo a su rebeldía.

Había recibido invitación del oficial de impuestos para que contribuyese a los gastos de la guerra con México y a sostener a la Iglesia. El "filósofo de los bosques" se negó terminantemente. Para su juicio, la guerra era impopular e injusta, y en cuanto a la Iglesia, él no aceptaba ser tenido como miembro de una sociedad a la que no había prestado su adhesión.

Durante toda una noche tuvo que meditar, entre rejas, el rebelde. $\mathrm{Y}$ aunque una de sus tías - compadecida de la contumacia del sobrino y anhelosa de verlo libre - pagó por él, no pudo evitar que de aquel incidente nacieran las soberbias páginas de un panfleto memorable: Desobediencia civil.

A partir de entonces, la actitud intelectual de Thoreau no declinó un minuto. Su Diario es pródigo en apuntes y sugerencias. Hasta que, en 1854, termina las magníficas páginas de Walden, tal vez el más completo de sus trabajos. El año anterior, Harriet Beecher Stowe acababa de publicar La cabaña del Tío Tom.

La atmósfera de la Unión cargábase ya de funestos presagios. Día a día era más insostenible el equilibrio entre sudistas y norteños. En torno al problema de la esclavitud arremolinábase la tormenta. Del centro del país había surgido un hombre extraño, leñador de origen, abogado de profesión, apóstol y político de vocación, Abraham Lincoln, contra quien se ensafiaba la furia de los ricos propietarios. El viejo partido antifederalista, desprestigiado y corrompido, se reagrupaba bajo el nombre de Republicano, con tendencia antiesclavista, democrática y popular, al lado de Lincoln.

Climax del drama, anuncio de su tragedia, en esos días el fanático John Brown dió principio a su campaña antiesclavista por casi todo el territorio. Indignados por el oleaje de protestas y el fermento de insurgencias que iba dejando tras de sí, los ricos lograron apresar a John Brown, en Harpers Ferry. Era en 1859. El primero en protestar contra el atropello fué Henry David Thoreau. Como siempre, resuelto a jugarse la vida a una sola carta, la de la justicia.

John Brown fué inicuamente sacrificado por el odio de los esclavistas, pero de su cuerpo torturado - John Brown's Body - surgió, primero la guerra, después la emancipación de los esclavos y la unidad de la nación. 
Cuando el 6 de mayo de 1862, enfermo de una inveterada bronquitis, hubo exhalado su último aliento Henry David Thoreau, ya Abe Lincoln era presidente de la República, y había comenzado, desde el trágico asalto a Fort Sumter, la agotadora y fecunda guerra civil.

\section{Boceto crítico}

Thoreau es un poeta, un poeta de la justicia, un auténtico poeta civil. Decirle moralista implica rebajarlo a lo pragmático. Entre Epicteto, Teofrasto, La Rochefoucauld, Gracián, Emerson. y él, existe una diferencia sustancial: todos ellos hablaron en términos absolutos, con una responsabilidad tan ilimitada que se diluía, combatiendo en el terreno de los principios, sin sacrificar sino ideas a la Idea. Thoreau no. El discutió y peleó en términos concretos, con una responsabilidad restricta y directa en el terreno de los hechos, y sacrificando la vida a la Idea. Difícilmente cabe diferencia mayor.

A primera vista el hombre de principios vive en un terreno abstracto y esa es su gloria y su miseria. Pero cuando el hombre de principios no se aparta de un terreno concreto, entonces ésta es su gloria y su dolor - sin miseria alguna. Thoreau fué asi. Por tanto, poeta antes que moralista $\mathrm{y}$, juntando ambos términos, hombre de los más cabales.

No es raro que todavía sea impopular entre algunos funcionarios de las letras de su patria: especie de levitas del orgullo nacional tan duramente fustigado por Thoreau, pero tan profundamente entendido por él.

Escribió poesías, cartas nutridas, numerosas páginas de diario, opúsculos, panfletos: en realidad, hombre de una sola pieza, su ins-. piración, encadenada al ideal del bienestar colectivo, pero sin sacrificar la chispa divina de la personalidad, aunaba de singular, de genial manera, lo teórico y lo práctico, las ideas de orgullo y de servicio, to ideal y lo consuetudinario, el vigor y la humildad. Impermeable a la transigencia cotidiana, poroso a la protesta de los oprimidos, campeón de la justicia y peón de la verdad, realiza en la puritana Nueva Inglaterra de mediados del siglo XIX' una tarea ciclópea e imperceptible, porque, de momento, los hechos políticos, llevando en su seno la hecatombe de la Guerra Civil, ahogaban toda 
voz que no fuera el grito exasperado y demagógico de John Brown o la admonición promisora y concretísima de Lincoln.

Otra voz, también de poeta, pero en verso, se levantó por aquel entonces, interpretando el optimista anhelo constructor de los norteamericanos: Walt Whitman, en cuyo estro, aunque tenido por inmoral, palpita con salvaje energía el individualismo indoblegable de los Pilgrim Fathers, hecho precepto severo y concreto en Desobediencia civil y $L a$ vida sin principio, norma general en Siete ensayos y clamor bárbaramente afirmativo y egoísta en Hojas de hierba.

Thoreau se rebela contra el Estado, porque no reposa en la justicia. Rechaza el Gobierno porque es un símbolo de opresión. Niega la fuerza de las mayorías, porque no son estables y dependen de la actividad de las minorías. Sus razonamientos descansan en una ancha base lógica, y son paradigmas de pureza doctrinal. En una página se pregunta: ¿por qué yo, maestro de escuela, he de contribuir con mi dinero a sostener a la Iglesia del Estado, y no han de ser los sacerdótes los que paguen tributo para sostener las escuelas? En otra razona asi: "Hay novecientos noventa y nueve protectores de la virtud por cada hombre virtuoso"... "Inclusive, hasta votar por lo justo no significa en modo alguno hacer algo por el justo. El voto no hace otra cosa que expresar ante los hombres un deseo nuestro, pero de débil modo."

Todas y cada una de las críticas de Thoreau poseen idéntica vivacidad. Ante ellas, como ante todo lo marmóreo, y lo rotundo, sólo caben dos actitudes: seguirlas o taparse los oídos. Los poderosos de su tiempo trataron de hacer lo último, pero voces tan potentes acababan abriéndose paso, y en los usos actuales de los Estados Unidos se advierte que no fué lección perdida la incesante 'campaña del solitario.

Asombra que un autor de tal magnitud sea tan poco difundido en Iberoamérica; más aún si consideramos la analogía reinante entre su estilo y personalidad y los de, por ejemplo, Manuel González Prada, Juan Bautista Alberdi, Francisco Bilbao y Juan Montalvo. Cuatro de los más grandes próceres de nuestra América, poseen rasgos comunes al autor de Walden, especialmente el primero de ellos.

Prada puso, como Thoreau, el anhelo moralizador por encima de cualquier otra pasión, y no temió a la soledad, sino antes bien la quiso como colaboradora, para acendrar su pureza. La prosa de 
Prada, cono la de Thoreau, es concisa, clara y compacta. Los versos, idealistas, pero no vagarosos, sino llenos de contenido. No se sabe de un "Diario" escrito por González Prada, puesto que no fué tan aislado en su vida doméstica y tuvo con quien dialogar en la más entrañable de las confidencias. En cambio, Thoreau contaba nada más que con árboles y los pájaros del bosque para gritar su angustia civica. Ambos, Thoreau y Prada, amaron la naturaleza con amor místico. Ambos tuvieron un sentido franciscano para con los animales. $Y$ ambos trabajaron y crecieron en horas de peligro, cuando en el país de uno se agitaban guerras exteriores y la tremenda guerra interior que conmovió hasta los cimientos mismos de la República; y cuando en la patria del otro, muchas guerras civiles, cruentas, y una gran guerra nacional, tan larga como la de Secesión en el Norte, hicieron virar en redondo los rumbos de la nacionalidad. Los dos contaron para combatir con armas semejantes: un estilo cuajado; metáforas naturales, espontáneas; vida ejemplar; capacidad de aislamiento; vocación de martirio; insumisión esencial ante lo consuetudinario.

Desobediencia civil y La vida sin principio, de Thoreau, se parecen a Horas de lucha y Bajo el oprobio, de González Prada; el Diario de aquél a El Tonel de Diógenes y Grafitos del segundo; Poemas del primero a Exóticas, Minuisculas y Baladas del último: las páginas sobre John Brown a las que Prada consagró en Páginas libres al desastre que entonces aquejaba al Perú. El uno se refugió en el bosque de Walden, entre árboles y pájaros; el otro en una casa, aislada, entre madreselvas y gorriones, capulíes fragantes y perros fieles.

La analogía con Montalvo es también tentadora. En general, Thoreau pertenece a la estirpe de nuestra mejor gente intelectual del siglo XIX: abocados a problemas complicados, a lo celeste y a lo terreno, a las Musas y a las Furias, al arte y a la política.

Sin embargo, casi no le conocemos. Y cuando el poeta chileno Vicente Huidobro escribía, en un artículo de La Nación de Santiago, agosto de 1941, que Thoreau era un desconocido para los sudamericanos, decía una gran verdad. No obstante, hay, por lo menos, un libro del solitario de Concord traducido al castellano: $W$ alden, bajo el título de $U n$ filósofo en los bosques, publicado en Buenos Aires, hace unos pocos años. 
Quienes hayan leido cualquiera de las obras de Thoreau saben cuán exacto, y hasta moderado, es el elogio que antecede. No será necesario que busquen mucho, en biografías inaccesibles, ni que lean los catorce volúmenes del Diario, empezado por el autor cuando tenía veinte años. Ni que devoren todos los poemas, ni tampoco, quizá, esa Seniana en Concord donde recoge la experiencia realizada en compañía de su hermano John, el año 1839, cuando ambos hicieron un paseo embriagándose de flores y de trinos. Buena prueba de lo que Thoreau era en materia de composición literaria nos la da, precisamente, ese bello manojo de impresiones, pues tardó en darle cima diez años, el que no era un preciosista sin embargo, sino un hombre con clara conciencia de su deber literario. (Otra semejanza con González-Prada y Montalvo, tremendos catadores de su propio estilo.) Bastará que revise el interesado el denso volumen publicado en Boston (19.37) por Henry Seidel Canbyuno, uno de los mejores críticos norteamericanos contemporáneos, bajo el título de Works of Thoreau, el mencionado tomito en castellano Un. filósofo en los bosques (Editorial Imán, Buenos Aires), o la selección en francés publicada por Rieder, de París, bajo el título de Désobeir, con un prólogo de Leon Bazalgette, debiendo tenerse en cuenta que dicha versión suprime algunos párrafos del texto, para evitar circunloquios hoy innecesarios, pero que, a nuestro juicio, son indispensables para saborear debida y profundamente la prosa y el pensamiento del egregio compañero de Ralph W. Emerson.

Porque en la obra de Thoreau todo vale, especialmente el matiz. Pertenece a la misma familia literaria del argentino Alberdi, para quien cada vocablo llenaba una función fisiológica en el discurso entero, tal como cada tendón, cada nerviecillo, cada músculo desempeña un rol en el organismo humano. Lejos de la facundia estruendosa y genial de Whitman, de la redondez de estilo de Emerson, sin la gracia mediterránea de Santayana, ni el inocultable, aunque leve, dogmatismo de William James, la prosa de Thoreau es de aquellas que poseen una buscada familiaridad, y que saben el secreto difícil de combinar la exaltación de sentimiento con la sencillez de la expresión. Así, cuando aborda el tema de John Brown, llega a alturas sorprendentes. No he leído, pese a largos saboreos del magnífico poema de Stephen Vincent Benet, "The John Brown's Body", tan celebrado por la crítica y los lectores de Estados Unidos, no he leído jamás algo tan, al mismo tiempo, ceñido $\mathrm{y}$ opulento, $7 \star$ 
conciso y elocuente, profundo y fácil sobre aquel precursor de la Revolución antiesclavista: en esos párrafos, Thoreau luce como un poeta, un polemista, un rebelde, un moralista y un maestro. Artista y ciudadano, o, mejor aún, ciudadano de dieciocho quilates porque era un artista de dieciocho quilates, su voz posee un secreto encanto viril, y busca y halla la cuerda sensible del hombre sin prejuicios, arrastrándolo invenciblemente a su camino y su ideario. ¿Qué más para un apóstol, y qué menos para un escritor tan de raza como Henry David Thoreau?

Luis Alberto Sánchez 